\title{
The difference of the gingival condition between diabetes mellitus and non diabetes mellitus patient on children at Cipto Mangunkusumo Hospital Jakarta
}

\author{
Wilda Kemala Maulani, Meirina Gartika*, Ina Hendiani** \\ *Departement of Pediatric Dentistry Fakultas Kedokteran Gigi Universitas Padjadjaran \\ **Departement of Periodontics Fakultas Kedokteran Gigi Universitas Padjadjaran
}

\section{ABSTRACT}

Diabetes mellitus is a systemic condition that affected the periodontium condition. The purpose of the research was to find the difference of the gingival condition between diabetes mellitus and non diabetes mellitus patient on children at Cipto Mangunkusumo Hospital (RSCM) Jakarta. The research method was descriptive comparative. The sample consist of 20 children with diabetes mellitus and 20 children non diabetes mellitus used purposive sampling. The gingival condition was scored by using Loe and Silness Gingival Index. The research showed that the average of gingival index in diabetes mellitus children was 1.1250 and non diabetes mellitus was 0.9562 . The statistic analysis was t-Test and the a was $5 \%$ showed that there was a significant difference gingival condition between diabetes mellitus patient and non diabetes mellitus patient on children. Conclusion showed a difference gingival condition between diabetes mellitus patient with non diabetes mellitus patient on children at RSCM Jakarta, the gingival condition of diabetes mellitus patient on children was more severe than non diabetes mellitus patient.

Key words: Diabetes mellitus, gingival condition

\section{INTRODUCTION}

Systemic diseases often have oral manifestations. One of the manifestations is diabetes mellitus. It is a disease that disrupts the metabolic system, especially the carbohydrate metabolism marked by hyperglicemy (high-blood glucose) resulted form insulin secretion disruption, insulin activity disruption or both. According to the American Diabetes Association, there are 2 general forms of diabetes, i.e. type 1 also referred as Insulin Dependent Diabetes or juvenile diabetes and type 2 Non Insulin Dependent Diabetes or adult onset diabetes.
It is reported that there are $5-10 \%$ type 1-diabetes of all diabetes cases with a frequent occurrence in children and young adults (under 30 years old). Two of 100 children between 5 and 18 years old were reported having type 1 diabetes. In 1995 , there were 812,500 cases, and it is predicted that in 2010 the number will up to $1,087,800$ cases. Whereas for type 2 diabetes, there were $90-95 \%$ of diabetes cases and often occur in adult (over 40 years old). More than 70\% type 2 diabetes patients were overweight. The type 2 diabetes is uncommon in children, but in several countries, there are $20 \%$ of children and adolescent patients. This change is related to increased incidence of 
obesity.

Diabetes is a systemic condition that affects the periodontium condition. Generally, diabetes mellitus patients have manifestations in their cavities, such as gingival enlargement, gingival polyp, abscess, periodontitis and tooth lost. Diabetes does not lead to gingivitis or periodontitis, but it leads to response changes of periodontium against local factors. Diabetes mellitus affects poriodontium tissue directly, modifies the tissue response towards local factors, and leads to gingival anatomy changes causing plaque accumulation and increases plaque periodontal severity-level.

Severe gingival inflammation, inner periodontal pocket, rapid bone lost, and periodontal abscess are frequently seen in diabetes patient with poor oral hygiene. Gingivitis and periodontitis are the most common oral manifestation in diabetes mellitus patients. Gingivitis in pediatric patient with diabetes is more severe than in children without diabetes. Diabetes patients who are more than 10 years old have bigger risk of experiencing periodontal tissue damage than patients under 10 years old.

\section{MATERIALS AND METHODS}

The materials and tools used in this study include mouth mirror, explorer, tweezers, probe, flashmild, cotton, 70\% alcohol, mask, gloves, rinse glass, informed consent, examination form, questionnaire, and writing tools. The method used is comparative descriptive with purpose sampling technique. The experiment was conducted on 13 March 2008-14 May 2008 in RSCM, Jalan Dipenogoro No. 71 Jakarta Pusat. The experimental method used is examination on selected teeth according to Green and Vermillion, i.e.: 1.1,1.6,2.6,3.1,3.6,4.6. If one of the teeth is missing, it is substituted by the adjacent tooth. The criteria of Loe and Silness gingival index assay are stated in the Table 1. The formula to count Gingival Index is:

Gingival value $/ 1$ tooth $=\underline{\text { Sum of total value per teeth }}$

Gingival index per person= Sum of total gum value per teeth Total teeth examined
Table 1. Loe and Silness gingival index.

\begin{tabular}{|c|c|c|}
\hline Score & $\begin{array}{c}\text { Gum } \\
\text { condition }\end{array}$ & Explanation \\
\hline 0 & Normal & $\begin{array}{l}\text { Pink and stippling appearance, } \\
\text { gummy, tappered interdental } \\
\text { papilla. }\end{array}$ \\
\hline 1 & $\begin{array}{l}\text { Mild } \\
\text { Gingivitis }\end{array}$ & $\begin{array}{l}\text { Little discoloration and edema, no } \\
\text { bleeding when probing }\end{array}$ \\
\hline 2 & $\begin{array}{l}\text { Moderate } \\
\text { Gingivitis }\end{array}$ & $\begin{array}{l}\text { Reddish gingiva, edema, and } \\
\text { bleeding when probing }\end{array}$ \\
\hline 3 & $\begin{array}{l}\text { Severe } \\
\text { Gingivitis }\end{array}$ & $\begin{array}{l}\text { Dark red appearance, edema, } \\
\text { ulceration, and tend to bleed } \\
\text { spontaneously }\end{array}$ \\
\hline
\end{tabular}

The gingivitis severity-level is divided into four: (1) normal gum with gingival index of 0 ; (2) mild gingivitis with gingival index 0.1-1.0; (3) moderate gingivitis with gingival index 1.12.0 (4) severe gingivitis with gingival index of 2.1-3.0. The data analysis is performed using a test for comparison of two means: two-way test. The hypothesis is tested for gingival condition of pediatric diabetes mellitus patients and nondiabetes mellitus pediatric patients at RSCM using t test.

\section{RESULT}

From the results, it is observed that there are two sample groups, pediatric diabetes mellitus patients at the Endocrinology Clinic of RSCM Jakarta, and pediatric non-diabetes mellitus patient at the Oral and Dental Clinic of RSCM Jakarta. The gingival condition of the pediatric diabetes mellitus at the Endocrinology Clinic of RSCM Jakarta shows that there are 6 mild gingivitis patients and 14 moderate gingivitis patients. The gingival condition of non-diabetes mellitus patients at the oral and dental clinic of RSCM Jakarta shows that there are 10 mild gingivitis patients and 10 moderate gingivitis patients (Table 2 ).

Table 3 shows that the average gingival index of pediatric diabetes mellitus patients at the Endocrinology Clinic of RSCM Jakarta is 1.1250 , which is categorized as moderate gingivitis. The gingival index of pediatric non-diabetes mellitus patients at The Oral And Dental Clinic of RSCM Jakarta is 0.9562 , which is categorized as mild 
Table 2. Gingival condition of pediatric diabetes mellitus and non-diabetes mellitus patients in RSCM Jakarta.

\begin{tabular}{ccccc}
\hline \multirow{2}{*}{ Gingival Index } & \multicolumn{2}{c}{ DM patient } & \multicolumn{2}{c}{ Non-DM patient } \\
\cline { 2 - 5 } & Total $(\mathrm{n})$ & Percentage $(\%)$ & Total $(\mathrm{n})$ & Percentage $(\%)$ \\
\hline Mild Gingivitis & 6 & 30.00 & 10 & 50.00 \\
Moderate Gingivitis & 14 & 70.00 & 10 & 50.00 \\
Severe Gingivitis & 0 & 0.00 & 0 & 0.00 \\
Total & 20 & 100.00 & 20 & 100.00 \\
\hline
\end{tabular}

Table 3. Gingival index average value for pediatric diabetes mellitus and non-diabetes mellitus patients in RSCM Jakarta.

\begin{tabular}{ccc}
\hline Score & $\begin{array}{c}\text { Gingival index } \\
\text { Average Value }\end{array}$ & Severity level \\
\hline DM Patient & 1.1250 & Moderate gingivitis \\
Non-DM Patient & 0.9562 & Mild gingivitiys \\
\hline
\end{tabular}

gingivitis.

The gingival index of the 20 samples is tested statistically using $\mathrm{t}$ test. The gingival index average for pediatric diabetes mellitus patient is 1.1250 with a standard deviation of 0.2112 and the gingival index of non-diabetes mellitus patient is 0.9562 with a standard deviation of 0.2767 . The standard deviation for pediatric diabetes mellitus patient is 0.2112 and the standard deviation for pediatric non-diabetes patient is 0.2767 .

\section{DISCUSSION}

The different gingival condition between diabetes mellitus and non-diabetes mellitus patients is influenced by the changes experienced by diabetes mellitus patients, such as vascular system change, collagen metabolism change, and PMN leukocyte dysfunction. The vascular system changes may exacerbate the periodontitis and decrease healing capacity. The collagen metabolism change may result in changes in healing process and periodontal damage because of the new collagen formation. PMD leukocyte dysfunction makes patients more susceptible to infection caused by PMN leukocyte dysfunction and it eventually leads to chemotactic disruption, imperfect phagocytosis or attachment disturbance.

The duration of the disease also influences the periodontium condition. Diabetes mellitus patient whose age is more than 10 years old is more susceptible to periodontal tissue damage

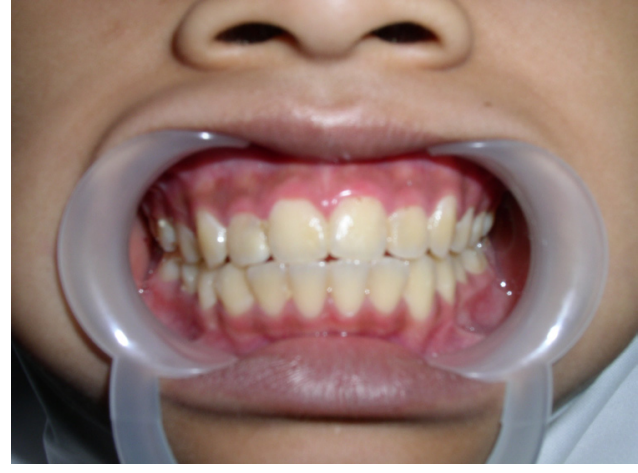

Figure 1. Mild gingivitis in pediatric diabetes mellitus patients in RSCM Jakarta (published on approval from the patient).

than under 10 years old-diabetes mellitus patients. There is no distinct periodontal structure lost among pediatric diabetes mellitus patients in RSCM Jakarta because most of them, i.e. 14 patients, have had diabetes mellitus for less than 5 years. Only 1 patient has suffered from diabetes for 10 years and 5 patients have the disease for 5 to 10 years.

Diabetes relates to increased gingival inflammation as a response to plaque bacteria, but glycemic control level is also an important variable in this connection. Patients with poor diabetes control have higher risk of getting periodontal disease. Diabetes control status can be observed from the level of $\mathrm{HbA} 1 \mathrm{c}$ in diabetes mellitus patients. ${ }^{1}$ The level of $\mathrm{HbA} 1 \mathrm{C}$ among pediatric diabetes mellitus patients in RSCM shows the following: HbA1c $>8 \%$ in 14 patients (poor diabetes control), $\mathrm{HbA} 1 \mathrm{C}$ of $7-8 \%$ in 6 patients (intermediate diabetes control).

Diabetes mellitus patients in RSCM Jakarta who have a blood sugar level of more than 126 $\mathrm{mg} / \mathrm{dL}$ are 17 while 1 patient shows a blood sugar level of 126 and 2 patients show a blood sugar level of $126 \mathrm{mg} / \mathrm{dL}$. The high blood glucose level leads to increased glucose in saliva and GCF (Gingival Cravicular Fluid) of the diabetes mellitus 
patients. Increased glucose in saliva enhances bacterial growth and plaque formation. Glucose level in GCF of diabetes mellitus patients is two times higher compared to other patients. This high glucose level in GCF may lead to changes in bacterial composition in plaque and will affect periodontal disease.

The gum that experiences gingivitis will be back to normal if plaque and calculus removal is performed and followed by good habit of maintaining oral hygiene. Diabetes patients with good glycemic receive similar treatment as non diabetes patients with no premedication necessary. Routine dental treatment in diabetes patients with poor glycemic control should be delayed until the diabetes is well controlled. Antibiotic premedication is needed to prevent infection. Controlled diabetes patients with periodontitis show good response to non-surgical therapy, periodontal surgery and maintenance, which is similar to the response of non diabetes mellitus patients. Uncontrolled diabetes patients show poor response towards surgical and nonsurgical periodontal therapy and deep pocket tends to recur rapidly.

\section{CONCLUSION AND RECOMMENDATION}

Based on the results of the study, it is concluded that there are differences of gingival condition between diabetes mellitus patients and non diabetes mellitus patients among pediatric patients in RSCM Jakarta. It is shown that gingival inflamation among pediatric diabetes mellitus patients is more severe than the non diabetes mellitus pediatric patients. The diabetes mellitus patients are more susceptible to gingival inflamation. Therefore, it is suggested that those patients control their metabolism, oral hygiene and routine scaling as the best prevention actions. Correct management of gingival inflammation may improve glycemic control in diabetes mellitus patients.

\section{REFERENCES}

1. Rose LF. et al. Periodontal medicine. St Louis: BC Decker Inc.; 2000. p. 121-5, 127, 130-5,1423.

2. Greenberg MS. Glick M. Burket's oral medicine diagnosis and treatment. $10^{\text {th }}$ ed. Ontario: BC Decker Inc.; 2003. p. 563-5,570-2.

3. Cameron AG, Widmer RP. Handbook of pediatric dentistry. Tokyo: Mosby; 1997. p. 253-4.

4. Moore PA. Zgibor JC. Dasanayake AP. Diabetes. a growing epidemic of all ages. JADA, 2003;134:11S.

5. Redding SW, Montgomery MT. Dentistry in Systemic Disease. Oregon: JBK Publishing, Inc, 1990. p. 140,142-4.

6. Newman MG, Takei HH, Klokkevold PR, et al. Carranza's Clinical periodontology. $10^{\text {th }}$ ed. Missouri: Saunders Elsevier; 2006. p. 46-8,613,284-8,355-60,657-60.

7. Lamb WH. Diabetes mellitus. Type 1.[cited 2008 Feb 10]. Available from:< http://www. emedicine.com>.

8. Vernillo AT. Dental considerations for the treatment of patients with diabetes mellitus. JADA 2003;134:25S-8S,31S.

9. Manson JD. Eley BM. Outline of periodontics. $4^{\text {th }}$ ed. New Delhi: Wright; 2000. p. 89.

10. Koch G. Poulsen S. Pediatric dentistry a clinical approach. Copenhagen: Munksgaard, 2001. p. 236,239-40.

11. Wilkins EM. Clinical Practice of the dental hygienist. $9^{\text {th }}$ ed. Philadelphia: Lippincott Williams\&Wilkins; 2005. p. 1084-5.

12. Baer PN, Benjamin SD. Periodontal disease in children and adolescents. Philadelphia: J.B. Lippincott Co.; 1974. p. 229.

13. Notoatmodjo S. Metodologi penelitian kesehatan. Jakarta: Rineka Cipta; 2005. p. $141-2$.

14. Sugiono. Statistika untuk penelitian. Bandung: Alfabeta; 2007. p. 68,117.

15. Ryan ME, Carnu O, Kamer A. The influence of diabetes on the periodontal tissues. JADA 2003;134:34S,36S-8S.

16. Panjaitan $M$. Berbagai jenis gula untuk penderita diabetes melitus dan pengaruhnya terhadap karies gigi. Maj Kedokt Gigi 1998;31:103.

17. Gehrig JSN, Willmann DE. Foundations of periodontics for the dental hygienist. Tokyo: Lippincott Williams \& Wilkins. 2003. p. 21,3843,59-62,105, 106.

18. Wilson TG. Kornman KS. Fundamentals of Periodontics. Warsaw: Quintessence Publishing Co, Inc, 1996. p. 254-6. 